Geo-Marine Letters

Volume 26, Number 1 / March, 2006 : 31-41

http://dx.doi.org/10.1007/s00367-005-0013-z

(c2006 Springer Science+Business Media
Archimer, archive institutionnelle de l'Ifremer http://www.ifremer.fr/docelec/

\title{
The western part of the Gulf of Cadiz: contour currents and turbidity currents interactions
}

\author{
T. Mulder ${ }^{1 *}$, P. Lecroart ${ }^{1}$, V. Hanquiez ${ }^{1}$, E. Marches ${ }^{1}$, E. Gonthier ${ }^{1}$, J.-C. Guedes ${ }^{2}$, \\ E. Thiébot ${ }^{3}$, B. Jaaidi ${ }^{4}$, N. Kenyon ${ }^{5}$, M. Voisset ${ }^{6}$, C. Perez $^{7}$, M. Sayago ${ }^{8}$, Y. Fuchey $^{9}$ and \\ S. Bujan ${ }^{1}$
}

(1) Département de Géologie et Océanographie, UMR 5805 EPOC, Université Bordeaux 1, Avenue des Facultés, 33405 Talence, Cedex, France

(2) Genavir, Port Brégaillon, 83500 LA Seyne sur Mer, France

(3) IUEM, 4 Place Nicolas Copernic, 29280 Plouzané, France

(4) Unité de Formation et de Recherche Océanologie-Géologie-Environnement-Aménagement, Département des Sciences de la Terre, University of Rabat, Avenue Ibn Battouta, B.P. 1014, Rabat, Morocco

(5) Challenger Division for Seafloor Processes, Southampton Oceanography Centre, Empress Dock,

Southampton, SO14 3ZH, UK

(6) DRO/GM, Ifremer Centre de Brest, B.P. 7029280, Plouzané, France

(7) Facultad de Ciencas del Mar, Universidad de Cadiz, 11510 Puerto Real, Cadiz, Spain

(8) Département de Géologie, Université de Genève, 13 Rue des Maraîchers, 1211 Geneva, Switzerland

(9) Department of Geology, University of Geneva, 13 Rue des Maraîchers, 1205 Geneva, Switzerland

*: Corresponding author : t.mulder@epoc.u-bordeaux1.fr

\begin{abstract}
:
Recent multibeam bathymetry and acoustic imagery data provide a new understanding of the morphology of the western part of the Gulf of Cadiz. The gulf is under the influence of a strong current, the Mediterranean Outflow Water (MOW). This current is at the origin of the construction of the giant Contourite Depositional System. Canyons and valleys with erosive flanks are observed. Only the Portimao Canyon is presently connected to the continental shelf. Channels occur on the continental shelf but are presently disconnected from the deeper network of channels and valleys. Slumps are localized in steep slope areas. They are caused by oversteepening and overloading, sometimes probably associated with earthquake activity. Slumps transform sharply into turbidity currents, depositing turbidites on the floor of deep valleys. Interaction of the MOW and gravity currents is suggested by the filling of the incisions located on the drifts below the present seafloor, the shifting of valleys and canyons in the direction of the MOW flow inducing an unusual phenomenon of capture of submarine valleys.
\end{abstract}




\section{Introduction}

The Gulf of Cadiz is located in the north-eastern Atlantic Ocean, northwest of the Strait of Gibraltar. It extends along the south Spanish and Portuguese continental margins (Fig. 1). The study area is situated at the termination of the Azores-Gibraltar transform fault (Srivastava et al. 1990) where Iberia and Africa converge in a NNW-SSE direction (Argus et al. 1989). An east-dipping subduction zone, with a shallow dipping fault plane, is present in the Gulf of Cadiz and extends below the Betic-Rif arc (Lajat et al. 1975; Maldonado et al. 1999; Gutscher et al. 2002). Consequently, the area is potentially seismogenic. For example, it is close to the source region of the Great Lisbon earthquake (M 8.7) of 1755 (Zitellini et al. 1999; Fig. 1).

The present circulation in the Gulf of Cadiz is controlled by the dynamics of the Mediterranean Outflow Water (MOW, Fig. 1) which is a strong current resulting from the exchange of water masses between the Mediterranean Sea and the Atlantic Ocean. This current has been active since the early Pliocene, after the Mediterranean basin was flooded following the Messinian salinity crisis (Vanney and Mougenot 1981; Mougenot and Vanney 1982; Mougenot 1988; Nelson et al. 1993). Presently, the MOW is a strong, warm $\left(13^{\circ} \mathrm{C}\right)$, and saline $\left(38 \mathrm{~g} \mathrm{l}^{-1}\right)$ current flowing out of the Mediterranean below the Atlantic waters (Ambar and Howe 1979; Ambar 1983). The water flux is balanced by the less-saline, cool water mass of the Atlantic inflow (Nelson et al. 1999) that flows back from the Atlantic into the Mediterranean. After passing the Strait of Gibraltar, the MOW is constrained in a W-SW channel and reaches velocities of $2.5 \mathrm{~m} \mathrm{~s}^{-1}$. West of $06^{\circ} 20^{\prime} \mathrm{W}$, the MOW temperature, salinity and velocity decrease. It veers north-westward under the influence of Coriolis force. The main MOW core (MC in Fig. 1) divides into two main cores that flow along the seabed at water depths of 300 to 1400 m (Madelain 1970; Zenk 1975; Ambar and Howe 1979; Gardner and Kidd 1983; Ochoa and Bray 1991; Johnson and Stevens 2000; Borenäs et al 2002): The Mediterranean Upper Water (MU in Fig. 1) and the Mediterranean Lower Water (ML in Fig. 1).

The Mediterranean Upper Water represents the upper, less-dense (salinity is 37.07 \%), warm $\left(13.7^{\circ} \mathrm{C}\right)$ core that flows at the base of the upper Spanish and Portuguese continental slopes at depths of 500-800 m. Its average velocity is $0.46 \mathrm{~m} \mathrm{~s}^{-1}$ (Meincke et al. 1975; Johnson et al. 2002).

The Mediterranean Lower Water constitutes the lower, more-saline (salinity is $37.42 \%$ ) that forms the main MOW nucleus. Its mean temperature is $13.6^{\circ} \mathrm{C}$ and it velocities ranges between 0.2 and $0.3 \mathrm{~m} \mathrm{~s}^{-1}$ (Zenk and Armi 1990; Bower et al. 1997). The ML divides into three minor branches between $6^{\circ} 20^{\prime} \mathrm{W}$ and $7^{\circ} \mathrm{W}$ which each follows separate deep channels (Madelain 1970; Kenyon and Belderson 1973) Mélières 1974; Nelson et al. 1993, 1999; García 2002): (1) the Intermediate Branch (IB in Fig. 2a) which moves northwestward through the Diego Cao Channel; (2) the Principal Branch (PB in Fig. 2a) considered to presently transport the MOW major flow (Madelain 1970) passing south of the Guadalquivir Bank through the Guadalquivir Contourite Channel and (3) the Southern Branch (SB in Fig. 2a) which follows a steep valley toward the southwest through the Cadiz Contourite Channel (Figs. 1 and 2).

At approximately 1,400 m water depth in the western part of the Gulf of Cadiz and at 1,200 m in the eastern part, the MOW loses contact with the seafloor. The velocity of the MOW is strongly influenced by seafloor morphology (Heezen and Johnson 1969; Madelain 1970; Thorpe 1972, 1976; Mélières 1974). The MOW accelerates when it is laterally constrained, and decelerates when it spreads.

The impact of the MOW on the sedimentation in the Gulf of Cadiz is considerable (Faugères et al. 1985b; McCave and Tucholke 1986). The strong MOW locally reworks sediment carried by rivers discharging into the gulf, mainly the Guadalquivir and Guadiana rivers (Fig. 1). The average grain size of the surface sediments decreases as the MOW velocity decreases westward. Consequently, the depositional system evolves from east to west. Close to Gibraltar, the energetic, main MOW core erodes, forming scours and gravel lags, followed westward by sand patches and ribbons (Habgood et al. 2003). Westward along the Spanish slope, contourite deposition forms large, elongated mounded and sheeted contourite drifts (Faugères et al. 1984, 1985a; Stow et al. 
1986; Llave et al 2001; Llave 2003; Hernández-Molina et al 2003). These drifts are composed essentially of thoroughly bioturbated, fine-grained sedimentary stacked sequences called contourites (Gonthier et al. 1984). The construction of the drifts is cyclic, being controlled by climatic and eustatic oscillations (Llave et al. 2001, 2005a, 2005b).

At the bend west of the Strait of Gibraltar, the MOW builds a giant unstable dissymmetric contouritic levee (Mulder et al. 2002, 2003). This levee is covered with mixed silt and mud waves, eventually only mud waves in its southern part (Kenyon and Belderson 1973; Gardner and Kidd 1983; Nelson et al. 1993, 1999; Migeon 2000), and with numerous sediment failures and flows in its northern part (Mulder et al. 2003). It is dissected by channels shifting progressively southward. Some of the most active channels (e.g., Gil Eanes in Fig. 1) terminate with small sandy lobes.

The morphology of the western part of the Gulf of Cadiz is only known by pioneer work of Vanney and Mougenot (1981). More recently, large coverage bathymetric tools have been used (Hernández-Molina et al. 2003) but they do not bring the accuracy of the EM300 multibeam used in this study.

In this paper, we present the new morphology derived from high-resolution multibeam bathymetry and acoustic imagery of the western part of the Gulf of Cadiz, in an area extending between $8^{\circ} 00^{\prime} / 9^{\circ} 20^{\prime} \mathrm{W}$ and $36^{\circ} 00^{\prime} / 37^{\circ} 00^{\prime} \mathrm{N}$.

\section{Materials and methods}

The data were collected during the CADISAR 2 cruise aboard the RV Le Suroit in September 2004. This cruise followed Cadisar 1 cruise dedicated to the study of the eastern part of the gulf (Mulder et al. 2003). Bathymetric data and acoustic imagery were acquired with a SIMRAD EM300 multibeam echosounder. This system operates at a frequency of $30 \mathrm{kHz}$ and a maximum angle of $150^{\circ}$, the swath width varying between 300 and $5000 \mathrm{~m}$ at water depths of 100 and $5000 \mathrm{~m}$, respectively. Ship speed was 5-5.5 knot.

The acoustic data were corrected for salinity and density effects using three conductivitytemperature-depth (SBE19) probes and 85 thermoprobes (Sippican). The tops of 21 Kullenberg piston cores and three USNEL box cores were used to visually control the grain size and interpret the acoustic imagery.

\section{$\underline{\text { Results }}$}

The western part of the Gulf of Cadiz presents five kinds of geomorphological structures: canyons and channels, deep-sea valleys and contourite channels, lobes, drifts and abyssal plains. These data show essentially large contourite drifts extending parallel to the continental slope interacting with erosional features formed by gravity currents moving downslope. Geographical names are based on Mougenot and Vanney (1982), Hernández-Molina et al. (2003) and Mulder et al. (2003).

\section{Canyons and channels}

Three canyons are visible on the map in Fig. 2a (from east to west): the Faro Canyon (FC in Figs. 1 and 2a), the Portimao Canyon (PC in Figs. 1 and 2a) and the Lagos Canyon (LC in Figs. 1 and 2a). The canyons are narrow with erosive flanks. The Faro and Lagos canyons incise the upper continental slope, whereas the Portimao Canyon incises the continental shelf.

The Faro Canyon is 20-km-long. It originates on the southern slope of the Albufeira Drift (AD in Fig. 2a). The Faro Canyon is bordered eastward by the Bartolome Dias Drift (BDD in Fig. 1) and merges sharply with the Portimao Valley (PV in Fig. 2a).

The Portimao Canyon is a slightly sinuous (sinuosity $=1.125$ ) canyon running N-S (Figs. 2a and 4). It is rooted on a N-S fault (Mougenot and Vanney 1982). The canyon head roots at isobath 120 $\mathrm{m}$, its depth varying from 165 to $340 \mathrm{~m}$ in the northern part and its width from 6.0 to $1.3 \mathrm{~km}$. Erosive gullies (g in Fig. 4) with clearly visible failure scars at their head form a "badland-like" morphology on the canyon flanks. Six bends are visible along the $55 \mathrm{~km}$ of the canyon course (b in Fig. 4). These bends are bordered by elongated terraces (width close to $850 \mathrm{~m}$ ) plastered along the 
canyon flanks with an elevation of $140 \mathrm{~m}$ above the axial thalweg. The terrace located at $36^{\circ} 45^{\prime} \mathrm{N}$, $8^{\circ} 32^{\prime} \mathrm{N}$ ( $\mathrm{t}$ in Fig. 4) appears to be due to a large slope failure that has been covered with the deposits of spilling turbidity currents (nested levees of Pichevin et al. 2001). The axial thalweg enlarges south of $36^{\circ} 30^{\prime} \mathrm{N}$, forming a valley that finally merges with the Portimao Valley.

The Lagos Canyon shows a more complicated morphology (Figs. 2a and 3). Its head is located at a water depth of about $760 \mathrm{~m}$, and runs towards SSW along less than $10 \mathrm{~km}$ and westward after a double bend (b1 and b2 in Figs. 2a and 3). Two chutes (c1 and c2 in Figs. 2a and 3) with a local slope of $10-11^{\circ}$, occur after the first and the second bend, respectively. The first chute corresponds to a narrowing of the canyon (constriction point, CPt in Fig. 2a). After the chute, the axial thalweg increases sharply to form a valley, the Lagos Valley (LV in Figs. 2a and 3) running NNE-SSW and merging with the Horseshoe Abyssal Plain (HAP in Fig. 2a) downstream of the second bend.

On the continental shelf, three channels with a depth reaching $150 \mathrm{~m}$ are observed between $8^{\circ} 53^{\prime}$ and $8^{\circ} 37^{\prime} \mathrm{W}$ (C1 to C3, Fig. 2a). The easternmost channel (C1 in Figs. 2a and 4) is the deepest. The two other channels (C2 and C3 in Fig. 2a) are not as deep (70 m) as C1. They have a straight course over $7 \mathrm{~km}$ and then bend westward before disappearing at a water depth ranging from 560 to $700 \mathrm{~m}$. Consequently, they are not connected to any valley on the continental slope. Southward extrapolation of the channel courses suggests that $\mathrm{C} 1$ could have been connected to the head of the Lagos Canyon, and that the most distal bend (b2) could have been connected to either to the westernmost channel (C3) or to the central channel (C2; Fig. 2). E-W seismic profiles across Portimao and Lagos drifts clearly show that a paleo-system of channels exists below the present surface of drifts (Fig. 7).

\section{Deep-sea channels and valleys}

Deep-sea channels and valleys have a flat bottom and are larger than canyons. They have no connection with the channel network on the upper continental slope and shelf or on the drifts located upslope.

The eight deep-sea channels and valleys shown on the map in Fig. 2 are the Intermediate Valley (IV in Fig. 2), the Don Carlos Valley (DCV in Fig. 2a), the Faro Valley (FV in Fig. 2a), the Lagos Valley (LV in Figs. 2a and 3), the Cadiz Valley (CV in Fig. 2a), the Guadalquivir Contourite Channel (GCC in Fig. 2a), the Portimao valley (PV in Fig. 2a) and the Cadiz Contourite Channel (CCC in Fig. 2a). Two are Contouritic Channels (Guadalquivir and Cadiz Contourite Channels). Six are valleys in which sedimentation is probably dominated by turbiditic processes

The 15-km-long Intermediate Valley (Figs. 2a and 4) is located just west of the Portimao Canyon. It merges quickly with the Portimao Valley.

The Faro Valley (Fig. 2a) forms the connection between the north branch of the Guadalquivir Contourite Channel and the Portimao Valley.

The Don Carlos Valley (Fig. 2a) connects the south branch of the Guadalquivir Contourite Channel and the Portimao Valley.

The Lagos Valley (Figs. 2a and 3) is located in the distal part of the Lagos Canyon and is $20 \mathrm{~km}$ long and $3 \mathrm{~km}$ wide. It presents a NNE-SSW direction, similar to the upper part of the Lagos Canyon. Distally the Lagos Valley merges with the Horseshoe Abyssal Plain at 3,550 m water depth.

The Cadiz Valley is located southward of the Albufeira High (AH in Fig. 2a), just west of the Lolita Mud Volcano (Somoza et al. 2003; LMV in Fig. 2a). It runs E-W and merges westward with the Horseshoe Abyssal Plain.

The Guadalquivir Contourite Channel (Hernández-Molina et al. 2003), runs on the southern side of the Guadalquivir Bank (GB in Fig.2A). At this location, the Guadalquivir Contourite Channel forms a bend with a large radius of curvature. It divides along the Portimao High (PH in Fig. 2a) into a north and a south branch. The north branch (nbGCC in Fig. 2a) passes north of the Portimao High and connects sharply with the Faro valley and then with the Faro Canyon. The south branch (sbGCC in Fig. 2a) passes south of the Portimao High and connects with the Don Carlos Valley. West of $8^{\circ} 03^{\prime} \mathrm{W}$, the channel enlarges, merging with the Portimao Valley. 
The Portimao Valley is longer than $50 \mathrm{~km}$ and has four main sources: (1) the Guadalquivir Contourite Channel (2) the Faro Canyon, (3), the Portimao Canyon, and (3) the Intermediate Valley. The northern flank of the Portimao Valley is steeper than the southern flank, the former corresponding to the continental slope. However, the southern flank presents abundant failure scars (FS in Fig. 2a), some suggesting a retrogressive process (Fig. 5). West of $9^{\circ} 10^{\prime} \mathrm{W}$, the Portimao valley merges with the Lagos Canyon. Both discharge into the Horseshoe Abyssal Plain.

The Cadiz Contourite Channel (Hernández-Molina et al. 2003) drains the lower core of the MOW. It is bordered to the north, from the Guadalquivir Diapiric Ridge (GDR in Fig. 2a) to the Albufeira High, by the deformed sheeted drift (DSD in Fig. 2a) of the central sector of the middle slope. It is connected laterally with the Cadiz Valley. The head of this valley is bounded in the north with the Albufeira High and a diapir line (D in Fig. 2a). This line consists of four diapirs, each of them forming a topographic high of 200-350 m elevation above the surrounding seafloor, with a more or less flat top and a diameter of 4-8 km. This diapir line is in the continuation of the tectonic lineament (including diapirs and rounded dissolution structures) observed in the eastern part of the gulf (Mulder et al. 2002; Fernández-Puga 2004; Medialdea et al 2004; Medialdea 2005).

Two additional contourite channels are partially visible on the eastern side of the map: the Huelva Contourite Channel (HCC in Fig. 2) and the Diego Cao Channel (DCC in Fig. 2).

The bottom of all the deep-sea channels and valleys lies at less than 1,400 $\mathrm{m}$ water depth, i.e., below the critical water depth at which the MOW do not flow on the seafloor. This suggests that the seafloor of the channels consists both of turbidites initiated by slope failures on the channel and canyon flanks, and of hemipelagic sediments coming in part from the suspended load of the MOW.

Mougenot and Vanney (1982) reported that the Portimao Canyon and large channels such as the Diego Cao/Huelva (DCC/HCC in Fig. 2a) and Alvares Cabral Moat (ACM in Fig. 2a) channels are oriented along major regional faults. Mulder et al. (2003) proposed that the present topography of the Gulf of Cadiz was strongly oriented by structural direction (tectonic lineament, and direction of the long axis of ponded basins and channels on the giant contouritic levee). This would suggest that present minor channels are also oriented along tectonic structures. In that case, they would represent tectonic depressions that are today maintained as topographic lows because of bypass or erosion due to the energetic MOW.

\section{Planaltos, topograhic highs and contourite drifts}

The study area shows part or the totality of seven marginal plateaus called "highs" as they represent topographic highs generally rooted on structural highs. They correspond to planaltos defined by Mougenot and Vanney (1982). They correspond to a sedimentary pile extending up to the Miocene or lower Pliocene, capped by a regional erosional or bypass surface. From east to west, these planaltos are named Faro (FP), Portimao (PP) and Lagos (LP, Vanney and Mougenot 1981; Figs. 1 and 2a). They are all covered by thin sheeted drifts. Two additional highs are located southward: the Albufeira and the Portimao highs. The Portimao High is located between the north and south branches of the Guadalquivir Contourite Channel. The Albufeira High is bordered by the south branch of the Cadiz Contourite Channel in the north and by the Cadiz Valley in the south.

The south edge of the Lagos Planalto is covered with sediment deformation (sd in Fig. 2a and Fig. 3). This deformation relates to the giant slump scar that affects the Planalto slope (GSS in Figs. 2a and 3).

Only the westernmost end of the Faro Planalto is visible in Fig. 2a.

In the eastern part of the gulf, Plio-Quaternary contourite drifts formed above the Neogene erosional surface. The Faro Drift (elongate mounded separated drift of Faugères et al. 1999; FD in Fig. 2a) is located at the top of the Faro Planalto. It is bordered in the north by a long moat that represents the termination of the Alvares Cabral Moat that merges with the Portimao Canyon at $8^{\circ} 32^{\prime}$ 'W, 364 ' N.

The Albufeira Drift (AD in Fig. 2a) is a smaller, elongate mounded separated drift representing the westward continuation of the Faro Drift on the east side of the Portimao Canyon. 
The Guadalquivir Bank (GB in Figs 1 and 2a) is topographic high of the Palaeozoic basement which locally outcrops. A sheeted drift is located in the northern side of the bank: the Bartolome Dias Drift (BDD in Fig. 2a). The bank is bordered southward by the Guadalquivir Contourite Channel draining the Principal Branch of the lower core of the MOW.

The Portimao and Lagos planaltos show a Plio-Quaternary cover that is concordant over the Neogene erosional surface (Fig. 2a). Consequently, they have been interpreted as sheeted drifts (Lagos, LD in Fig. 2a) or relict and deformed sheeted drifts (Portimao, PD in Figs. 2a and 3) by Hernández-Molina et al. (2003). These drifts show a flat surface gently dipping southward or southwestward with no sedimentary features. This is a major difference with the sedimentary levee described above for the eastern part of the gulf that is covered with sediment waves or slope instabilities. The small drift reported in the northern part of the Sagres Planalto (west of the study area, SP in Fig. 1) by Mougenot and Vanney (1982) is not included in the study area.

The Lagos, Portimao and Albufeira drifts show clearly a N-S morphology in their north part bending progressively toward the W-SW in their south part. This is probably due to a change in the progradation trend under the activity of the E-W motion of the MOW lower core that becomes prominent seaward. The south termination of the drifts is clearly erosional indicating the strong energy of the lower core of the MOW.

\section{Depositional lobes.}

Depositional lobes have been described in the southern part of the Gulf of Cadiz (Habgood et al. 2003; Mulder et al. 2003), i.e., in the south-eastern sector of the present study area. These are located at sites where sandy cores were evaluated by Mélières (1974). They are typically less than $10 \mathrm{~km}$-long and less than $20 \mathrm{~m}$-thick, consisting of very clean fine sand and coarse silt. The acoustic imagery (Fig. 6) of a lobe laying at the connection between the Cadiz Contourite Channel and the Cadiz Valley (Fig. 1) shows that it is composed of several sedimentary bodies of different reflectivity, suggesting several stages for lobe deposition.

Visual examination of surficial material from cores collected at various sites in the western Gulf of Cadiz, either in lobes or in channel turbidites (see location in Fig. 2b), show the widespread occurrence of largely sandy sediments. These could be supplied either by Spanish rivers, or more probably by the erosion of lower Pliocene sands (Vanney and Mougenot 1981).

\section{Discussion}

\section{Activity of the MOW}

In the western Gulf of Cadiz, the activity of the Mediterranean Outflow Water is strongly reflected in trends shown by the Lagos, Portimao and Albufeira drifts. Their orientation on the bathymetric map is N-S and they bend progressively E-W. On seismic profiles, the drifts (especially Albufeira) have a marked migration toward the west that adds to their classical upslope progradation (toward north). The southern part of the Lagos and Portimao drifts is eroded by gullies due to the gravity processes and by the Lower core of the MOW. Indeed, signs of gravitational deformation exist at the south end of the Lagos Planalto. The south edge of the drifts shows to a strong increase in the slope (value close to $10^{\circ}$ ). In addition, this edge is located at $850-1,050 \mathrm{~m}$ water depth, which corresponds to the maximum depth where MOW is encountered in this area.

The flat morphology of the top of the Portimao and Lagos sheeted drifts is also a consequence of MOW activity. At present, in the western part of the gulf, MOW velocity does not exceed $0.3 \mathrm{~m} \mathrm{~s}^{-1}$. This low velocity is mainly due to the spreading of the upper core of the MOW west of Portimao Canyon. At this location, the upper core is more tabular because it is less affected by the sea-floor morphology compared with the central sector of the middle slope where recent tectonic activity has been more important, and controls the sea-floor morphology (Hernández-Molina et al. 2005). This is sufficient to rework clay and fine silts and flatten the top of the drift but is insufficient to transport coarser particles. Consequently, the grain size of the particles and the flow intensity are too small to form any sedimentary features at the top of the drifts. 


\section{Mass movements}

Mass movements such as slumps and slides are probably the most frequent gravity processes in the study area. These are evidenced by the presence of well-defined slump scars, for example, on the south flank of the Portimao Valley, and by the "badland" shape of the channels, drifts and canyons. The gullies at the origin of the badland shape show circular structures at their heads, suggesting formation by retrogression (Figs. 3 and 4). In the western part of the gulf, the types of mass movements are less varied than in the eastern part of the Gulf, where gravity processes are essentially sediment flows moving on the gentle slope of the contouritic levee (Mulder et al. 2003). In addition, in the western part of the Gulf, gravity processes appear in the form of slumps turning sharply turbidity currents on steep slopes. Indeed, no slump deposits are visible. These slumps are probably due to oversteepening and overloading resulting from drift progradation and earthquake activity. Thus, large-scale failures, such as that on the south edge of the Lagos Planalto, suggest regional sediment instability due to earthquake activity.

\section{Turbiditic activity}

Turbiditic activity is demonstrated by the presence of turbiditic sequences in cores taken at the bottom of the Portimao Canyon and Valley. The canyons, valleys and gullies channel turbidity currents resulting mainly from the transformation of slope failures observed on the slopes.

\section{Interactions between gravity processes and contour currents}

Interaction of the MOW and gravity processes, in particular turbidity currents, is evidenced by the present-day disconnection between channels on the continental shelf and canyons and valleys, the filling of valleys and the capture of submarine valleys. Present disconnection between the channels located on the continental shelf and the valleys and canyons observed on the continental slope is particularly visible west of the Portimao Canyon. At present, no connection exists between the Lagos Canyon and any of the three channels identified upslope. Similarly, east of the Portimao Canyon, the Faro Canyon is not connected to any conduit on the Albufeira Drift and on the continental shelf.

In addition, both the Lagos and Faro canyons have flanks smoother than those of the Portimao Canyon. In the former two canyons the erosive morphology of canyon flanks is less visible than for the Portimao Canyon, suggesting that flank erosion is not active today, and that these valleys are being progressively infilled by sediment load, i.e., drift progradation.

Evidence of a paleo-channel system below the present-day surface of the Portimao and Lagos drifts suggests that in the past, the network of submarine valleys was connected to the channels located at the top of the drifts or on the continental shelf. By implication, the present disconnection is due to an imbalance between the energy of the MOW and the activity of the turbidity currents. During warm periods and probably during the entire Holocene, sediment load from the continent and turbiditic activity are less important than during cold periods for the region (Hernández-Molina et al. 2002). In addition, the lower core of the MOW was located deeper during cold periods than at present and was more active (Schönfeld and Zahn 2000; Llave et al. 2005a). Consequently, during periods of higher MOW activity (cold periods), the most energetic process acting on the upper slope would be downslope gravity events, mainly linked to turbidity currents (Hernández-Molina et al 2002). During these periods, channels incise the drifts and are connected to valleys and canyon heads downslope. During periods of low MOW activity, by contrast, sediment load from the continent and turbiditic activity both decrease. Although MOW energy also decreases, it becomes larger than that of downslope gravity processes. Channels progressively fill, and the turbiditic activity is concentrated only at some specific locations, such as the Portimao Canyon at the present time.

Valley and canyon capture is suggested mainly by the singular double-bend shape of the Lagos Canyon and the constriction located at $36^{\circ} 36^{\prime} \mathrm{N} / 8^{\circ} 53^{\prime} \mathrm{W}$ associated with a change in the canyon course. The shape of the Lagos Valley suggests it was initially connected to a canyon that was itself 
connected to channel C3. Other canyons or valleys were probably connected to channels C2 and $\mathrm{C} 1$. Because of the westward progradation of the Lagos Drift, the canyon connected to either C2 or C1 progressively shifted toward the west, forming the northernmost bend. This bend connected at some stage with the Lagos Valley. The constriction thus corresponds to a capture point formed according to a process mimicking that in subaerial river systems.

\section{Conclusions}

This paper brings new results on the western part of the Gulf of Cadiz.

- The structural control on the morpho-sedimentary of the gulf is confirmed, for example, by the course of channels following diapir lines.

- The decreasing energy and competency (maximum size of carried particles) toward the west is evidences by the construction of fine-grained contourite drifts. No mesoscale sedimentary structures or evidence of erosion from the MOW are visible at the top of the drifts.

- Sediment instability is present in the western part of the gulf, as it is in the eastern part, but, the morphology of the failures differs. In the eastern part, small slope failures are generated mainly by overloading and shearing by the MOW. In the western part, large slope failures are due to oversteepening and probably, for very large failures, to earthquake activity, as this part is closer to the tectonically active accretionary prism than does the eastern part.

- The impact of downslope gravity processes on sedimentation and seafloor morphology is more important in the western part than in the eastern part of the gulf because the energy of the alongslope MOW is less intense in the former. Turbidite sedimentation dominates in deep-sea canyons and valleys. In addition, because the MOW flows detached from the seafloor in most of the western part, particles transported by the MOW settle as hemipelagites, rather than as contourites.

- When energy of gravity processes and MOW are balanced, both processes can interact. This interaction generates phases of erosion of channels and canyons when downslope supply and gravity processes dominate, and phases of canyon and channel filling when MOW dominated. Downslope supply seems to dominate during cold periods (when river load is large and MOW deepens) although the activity of the lower MOW core increases. Conversely, upper MOW core is more active during interglacial period, compared with the lower core. This highest activity could increase erosion on the upper slope

\section{Acknowledgements}

We thank the crew of the RV Le Suroît for its technical assistance during the Cadisar 2 cruise, Pr. Hernández-Molina for reviewing the manuscript and the editorial board of Geo-Marine Letters for improvement in English and editing the manuscript. UMR CNRS 5805 contribution number 1573. 


\section{$\underline{\text { References }}$}

Ambar I (1983) A shallow core of Mediterranean water off western Portugal. Deep Sea Res, 30(6A): 677-680

Ambar I, Howe MR (1979) Observations of the Mediterranean Outflow. I Mixing in the Mediterranean Outflow. Deep-Sea Res 26A: 535-554

Argus DF, Gordon RG, Demets C, Stein S (1989) Closure of the Africa-Eurasia-North America plate motion circuit and tectonics of the Gloria fault. J Geophys Res 94: 5585-5602

Borenäs KM, Walhin AK, Ambar I, Serra N (2002) The Mediterranean outflow splitting - a comparison between theoretical models and CANIGO data. Deep-Sea Res II, 49: 4195-4205

Bower A, Armi L, Ambar I (1997) Lagrangian observations of meddy formation during a Mediterranean undercurrent seeding sediment. J Phys Oceanogr 27(11): 2545-2575

Faugères J-C, Gonthier E, Stow DAV (1984) Contourite drift molded by deep Mediterranean outflow. Geology 12: 296-300

Faugères J-C, Cremer M, Monteiro H, Gaspar L (1985a) Essai de reconstitution des processus d'édification de la ride sédimentaire du Faro (marge sud-portugaise). Bull Inst Géol Bassin Aquitaine 37: 229-258

Faugères J-C, Frappa M, Gonthier E, Grousset FE (1985b) Impact de la veine d'eau méditerranéenne sur la sédimentation de la marge sud et ouest ibérique au Quaternaire récent. Bull Inst Géol Bassin Aquitaine 37: 259-287

Faugères J-C, Stow DAV, Imbert P, Viana A (1999) Seismic features diagnostic of contourite drifts. Mar Geol 12: 1-38

Fernández-Puga MC (2004) Diapirismo y estructuras de expulsión de gases hidrocarburos en el talud continental del Golfo de Cádiz. PhD Thesis, Facultad de Ciencias del Mar, Universidad de Cádiz

García M (2002) Caracterización morfológica des sistema de canales y valles submarinos des talud medio del Golfo de Cádiz (SO de la Península Ibérica): implicaciones oceanográficas. Tesis de Licenciatura, Facultad de Ciencias del mar. Universidad de Cádiz

Gardner JV, Kidd RB (1983) Sedimentary processes on the Iberian continental margin viewed by long-range side-scan sonar. Part 1. Gulf of Cadiz. Oceanol Acta 6(3): 245- 253

Gonthier E, Faugères J-C, Stow DAV (1984) Contourite facies of the Faro drift, Gulf of Cadiz. In: Stow DAV, Piper DJW (eds) Fine grained sediments: deep water processes and facies. Geol Soc Spec Publ 4: 275-292

Gutscher M-A, Malod J, Réhault J-P, Contrucci I, Klingelhöfer F, Mendes-Victor L, Spakman W, SISMAR scientific team (2002) Evidence for active subduction beneath Gibraltar. Geology 30: 1071-1074

Habgood EL, Kenyon NH, Akhmetzhanov A, Weaver PPE, Masson DG, Gardner J, Mulder T (2003) Deep-water sediment wave fields, bottom current sand channels and gravity flow channel-lobe systems: Gulf of Cadiz, NE Atlantic. Sedimentology 50(3): 483-510

Heezen B, Johnson (1969) Mediterranean undercurrent and microphysiography west of Gibraltar. Bull Inst Oceanogr Monaco 67(1382): 1-95

Hernández-Molina FJ, Somoza L, Vázquez JT, Lobo F, Fernández-Puga MC, Llave E, Díaz del Río V (2002) Quaternary stratigraphic stacking patterns on the continental shelves of the southern Iberian Peninsula: their relationship with global climate and palaeoceanographic changes. Quat Int 921(1): 5-23

Hernández-Molina FJ, Llave E, Somoza L, Fernández-Puga MC, Maestro A, León R, Barnolas A, Medialdea T, García M, Vázquez JT, Díaz del Río V, Fernández-Salas, LM, Lobo F, Alveirinho Dias JM, Rodero JY Gardner J (2003) Looking for clues to paleoceanographic imprints: a diagnosis of the gulf of Cadiz contourite depositional systems. Geology 31(1): 19-22

Hernández-Molina FJ, Llave E, Stow DAV, García M, Somoza L, Vásquez JT, Lobo F, Maestro A, Díaz del Río V, León R, Medialdea T, Gardner J (2005) The Contourite Depositional System of the Gulf of Cadiz: a sedimentary model related to the bottom current activity of the 
Mediterranean Outflow Water and the continental margin characteristics. Deep-Sea Res (in press)

Johnson J, Stevens I (2000) A fine resolution model of the eastern North Atlantic between the Azores, the Canary Islands and the Gibraltar Strait. Deep-Sea Res I 47: 875-899

Johnson J, Ambar I, Serra N, Stevens I (2002) Comparative studies of the spreading of Mediterranean water through the Gulf of Cadiz. Deep Sea Res Part II. Topical Studies in Oceanography vol 49 (19) pp 4179-4193

Kenyon NH, Belderson RH (1973) Bed-forms of the Mediterranean undercurrent observed with side-scan sonar. Sediment Geol 9: 77- 99

Lajat D, Biju-Duval B, Gonnard R, Letouzey J, Winnock E (1975) Prolongement dans l'Atlantique de la partie externe de l’arc bético-rifain. Bull Soc Géol Fr 7(4): 481-485

Llave E (2003) Análisis morphosedimentario y estratigráfico de los depósitos contorníticos del Golfo de Cádiz: Implicaciones paleoceanograficas. PhD, Facultad de Ciencas del Mar, Universidad de Cádiz

Llave E, Hernández-Molina FJ, Somoza L, Díaz del Río V, Stow DAV, Maestro A, Alveirinho Dias JM (2001) Seismic staking pattern of the Faro-Albufeira contourite system (Gulf of Cadiz): a Quaternary record of paleoceanográphic and tectonic influences. Mar Geophys Res 22: 487-508

Llave E, Schönfeld J, Hernández-Molina FJ, Mulder T, Somoza L, Díaz del Río V (2005a) Highresolution stratigraphy of the Mediterranean outflow contourite system in the Gulf of Cadiz during the Late Pleistocene: the impact of Heinrich events. Mar Geol (in press)

Llave E, Hernández-Molina FJ, Somoza L, Stow DAV, Díaz del Río V (2005b) Quaternary evolution of the contourite depositional System in the Gulf of Cadiz. In: Viana A, Rebesco M (eds) Economic and paleoceanographic importance of contourites. Geol Soc Lond Spec Publ (in press)

Madelain F (1970) Influence de la topographie du fond sur l'écoulement méditerranéen entre le détroit de Gibraltar et le Cap Saint Vincent. Cahiers Océanogr 22: 43-61

Maldonado A, Somoza L, Pallarés L (1999) The Betic orogen and the Iberian-African boundary in the Gulf of Cadiz: geological evolution (central North Atlantic). Mar Geol 155: 9-43

McCave IN, Tucholke BE (1986) Deep current-controlled sedimentation in the western North Atlantic. In: Vogt PR, Tucholke BE (eds) The geology of North America, vol M. The Western North Atlantic region. Decade of North America Geology, Geological Society of America, Boulder, CO, pp 451-468

Medialdea T (2005) Estructura y Evolución Tectónica del Golfo de Cádiz. PhD Thesis Facultad de Ciencas Geológicas. Universidad Complutense

Medialdea T, Vegas R, Somoza L, Vázquez JT, Maldonado A, Díaz del Río V, Maestro A, Córdoba D, Fernández-Puga MC (2004) Structure and evolotion of the "Olistostrome" complex of the Gibraltar Arc in the Gulf of Cadiz (eastern Central Atlantic): evidence from two long se’ismic cross-sections. Mar Geol 209: 173-198

Meincke J, Siedler G, Zenk W (1975) Some current observations near the continental slope off Portugal. Meteor Forsch Ergebnisse, A, 16: 15-22

Mélières F (1974) Recherches sur la dynamique sédimentaire du Golfe de Cadix (Espagne). Thèse Doctorat d'Etat, Univ Paris 6, no A10206

Migeon S (2000) Dunes géantes et levées sédimentaires en domaine marin profond: approche morphologique, sismique et sédimentologique. PhD thesis Univ Bordeaux 1

Mougenot D (1988) Géologie de la marge portugaise. Thèse Doctorat d'Etat, Univ Paris 6

Mougenot D, Vanney JR (1982) Les rides de contourites plio-quaternaires de la pente continentale sud-portugaise. Bull Inst Géol Bassin Aquitaine 31: 131-139

Mulder T, Lecroart P, Voisset M, Schönfeld J, Le Drezen E, Gonthier E, Hanquiez V, Zahn R, Faugères J-C, Hernández-Molina EJ, Cadisar scientific party (2002) Past deep-ocean circulation and the paleoclimate record-Gulf of Cadiz. EOS, American Geophys Union Trans 83(43): 481488 
Mulder T, Voisset M, Lecroart P, Le Drezen E, Gonthier E, Cadisar scientific party (2003) The Gulf of Cadiz: an unstable giant contouritic levee. Geo-Mar Lett 23: 7-8

Nelson CH, Baraza J, Maldonado A (1993) Mediterranean undercurrent sandy contourites, Gulf of Cadiz, Spain. In: Stow DAV, Faugères J-C (eds) Contourites and bottom currents. Contourites and hemipelagites in the deep-sea. Sediment Geol 82: 103-131

Nelson CH, Baraza J, Maldonado A, Rodero J, Escutia C, Barber JH Jr (1999) Influence of the Atlantic inflow and Mediterranean outflow currents on Quaternary sedimentary facies of the Gulf of Cadiz continental margin. In: Maldonado A, Nelson CH (eds) Evolution of the Iberian Margin and the Gulf of Cadiz. Mar Geol 155: 99-129

Ochoa J, Bray NA (1991) Water mass exchange in the Gulf of Cadiz. Deep-Sea Res 38(1): S465S503

Pichevin L, Mulder T, Savoye B, Cremer M, Piper D.J.W, Gervais A. (2001) The Golo submarine system (east-Corsica margin): turbidite system morphology and processes of terrace formation from high-resolution seismic Boomer profiles. Geo-Mar Lett 23(2): 117-124

Schönfeld J, Zahn R (2000) Late glacial to Holocene history of the Mediterranean outflow. Evidence from benthic foraminiferal assemblages and stable isotopes at the Portuguese margin. Palaeogeogr, Palaeoclimatol, Palaeoecol, 159: 85-111

Somoza L, Díaz-del-Rio V, León R, Ivanov M, Fernández-Puga MC, Gardner JM, HernándezMolina FJ, Pinheiro LM, Rodero J, Lobato A, Maestro A, Vázquez JT, Medialdea T, FernándezSalas LM (2003) Seabed morphology and hydrocarbon seepage in the Gulf of Cadiz mud volcano area: acoustic imagery, multibeam and ultra-high resolution data. Mar Geol 195: 153176

Srisvastava SP, Schouten H, Roest WR, Klitgord KD, Kovacs LC, Verhoef J, Macnab R (1990) Iberian plate kinematics: a jumping plate boundary between Eurasia and Africa. Nature 344: 756-759

Stow DAV, Faugères J-C, Gonthier E (1986) Facies distribution and drift growth during the late Quaternary (Gulf of Cadiz). Mar Geol 72: 71-100

Thorpe SA (1972) A sediment cloud below the Mediterranean outflow. Nature 236: 326-327

Thorpe SA (1976) Variability of the Mediterranean undercurrent in the Gulf of Cadiz. Deep-Sea Res 23: 711-727

Vanney JR, Mougenot D (1981) La plate-forme continentale du Portugal et les provinces adjacentes: analyse géomorphologique. Memorias dos Serviços Geologicos de Portugal 28, pp 186

Zenk W (1975) On the Mediterranean outflow west of Gibraltar. Meteor Forscir. Ergebuisse A(16): 23-34

Zenk W, Armi L (1990) The complex spreading patterns of Mediterranean water off the Portuguese continental slope. Deep-Sea Res 37: 1805-1823

Zitellini N, Chierici F, Sartori R, Torelli L (1999) The tectonic source of the 1755 Lisbon earthquake and tsunami. Ann Geofis 42: 49-55 


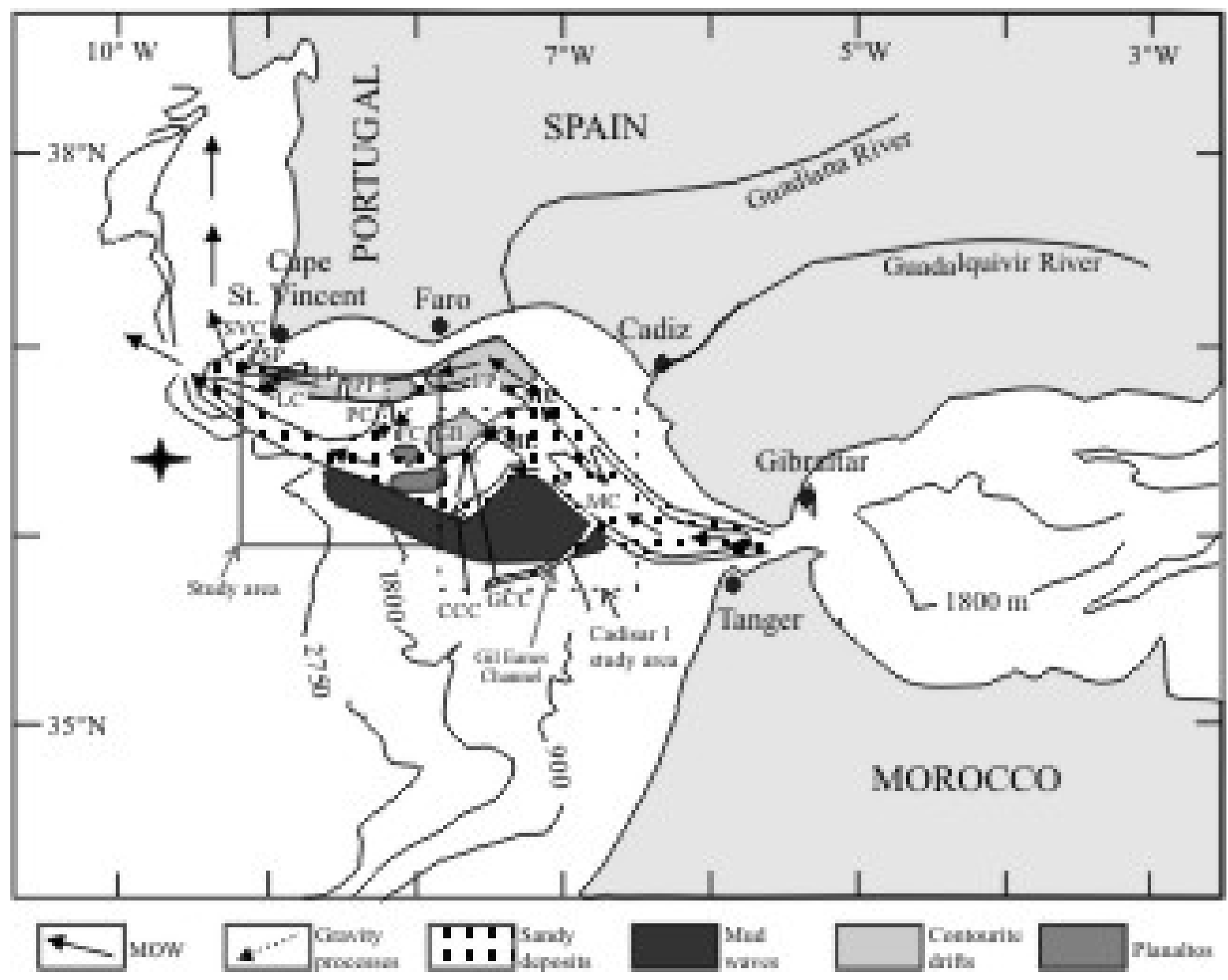

Fig. 1 General map of the Gulf of Cadiz showing the cores of the Mediterranean Outflow Water (MOW) and site of downslope gravity processes. Plain frame: area studied during Cadisar 2 cruise (this study). Dashed frame: area studied during Cadisar 1 cruise. CCC: Cadiz Contourite Channel; FC: Faro Canyon; FP: Faro Planalto; GB: Guadalquivir Bank; GCC: Guadalquivir Contourite Channel; LC: Lagos Canyon; LP: Lagos Planalto; MC: main MOW core; PC: Portimao Canyon; PP: Portimao Planalto; SP: Sagres Planalto; SVC: St. Vincent Canyon. The star indicates the epicenter of the 1755 Lisbon earthquake 

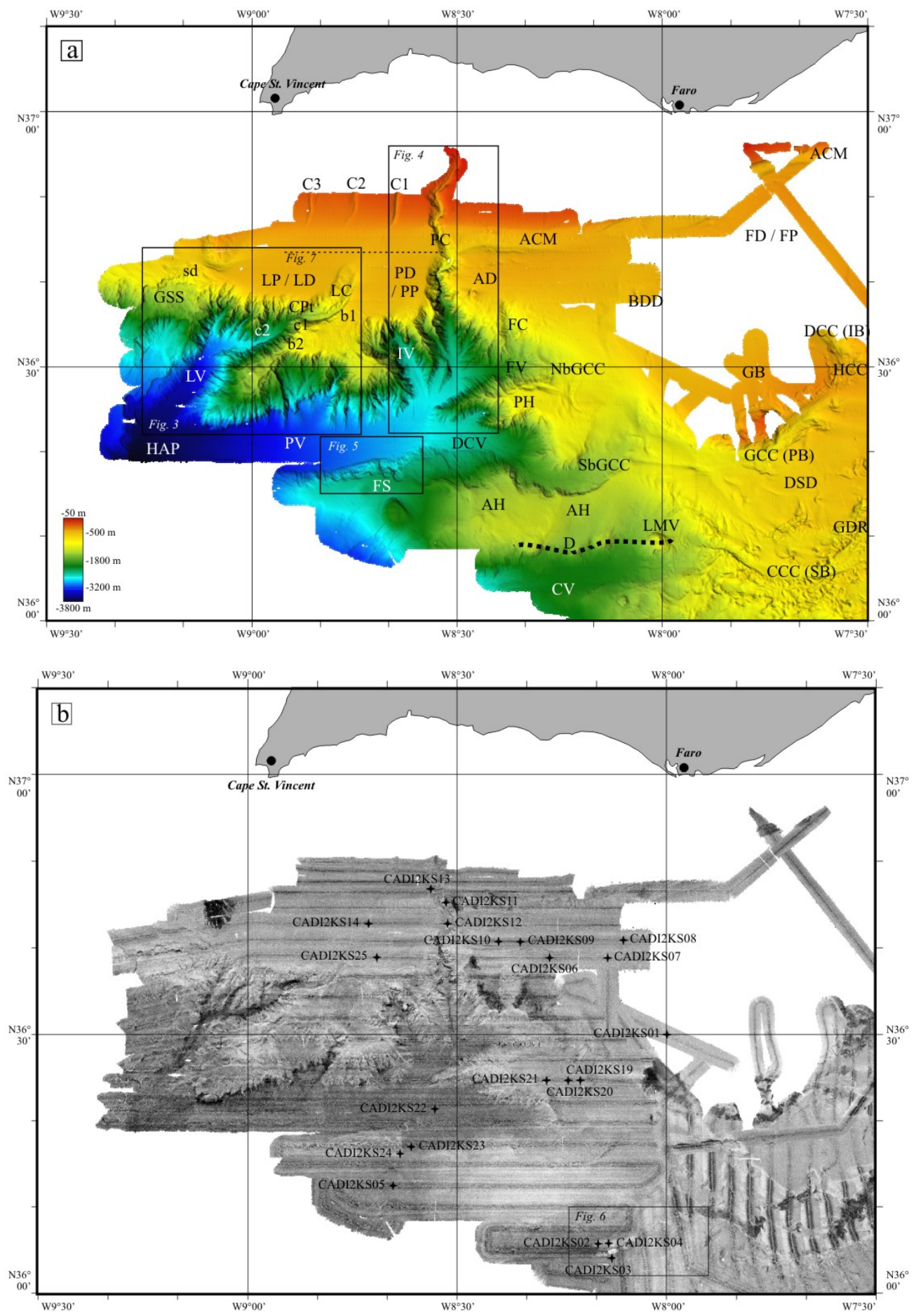

Fig 2a High-resolution ( $30 \times 30 \mathrm{~m}$ grid) EM 300 bathymetric map of the western part of the Gulf of Cadiz studied during the Cadisar 2 cruise. ACM: Alvares Cabral Moat; AD: Albufeira Drift; AH; Albufeira High; b1, b2: bends of the Lagos Canyon; BDD: Bartolome Dias Drift; c1, c2: chutes of the Lagos Canyon; C1, C2, C3: channels on the continental shelf; CV: Cadiz Valley; CPt: constriction point; sd: sediment deformation; (nb) (sb) GCC: (north branch) (south branch) Guadalquivir Contourite Channel; DCC: Diego Cao Channel; DCV: Don Carlos Valley; DSD: Deformed sheeted drift; FD: Faro Drift; FV: Faro Valley; FS: failure scars; GDR: Guadalquivir Diapiric Ridge; GSS: giant slump scar; HAP: Horseshoe Abyssal Plain; HCC: Huelva Contourite Channel; IV: Intermediate Valley; LD: Lagos Drift; LV: Lagos Valley; LMV: Lolita Mud Volcano; PD: Portimao Drift; PH: Portimao High; PV: Portimao Valley. Red dotted line indicates the diapir line (D). For other abbreviations, see Fig. 1. b High- resolution (12.5 x 12.5 m grid) EM 300 acoustic imagery map of the western part of the Gulf of Cadiz studied during the Cadisar 2 cruise. Crosses are core locations 


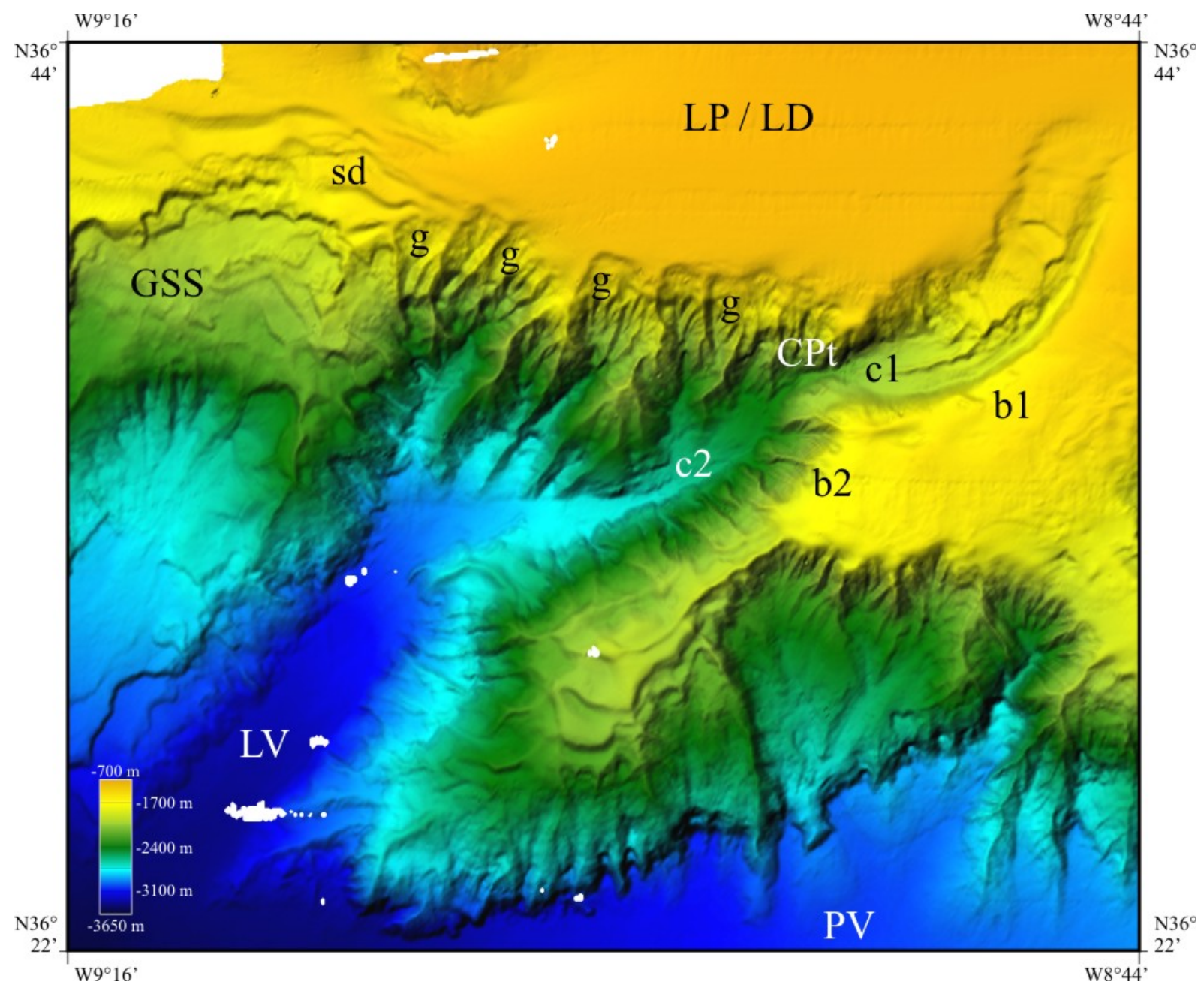

Fig. 3 Detailed bathymetric map of the Lagos Channel, Planalto and Drift. g: gullies on canyon and valley flanks; For other abbreviations, see Figs. 1 and 2 


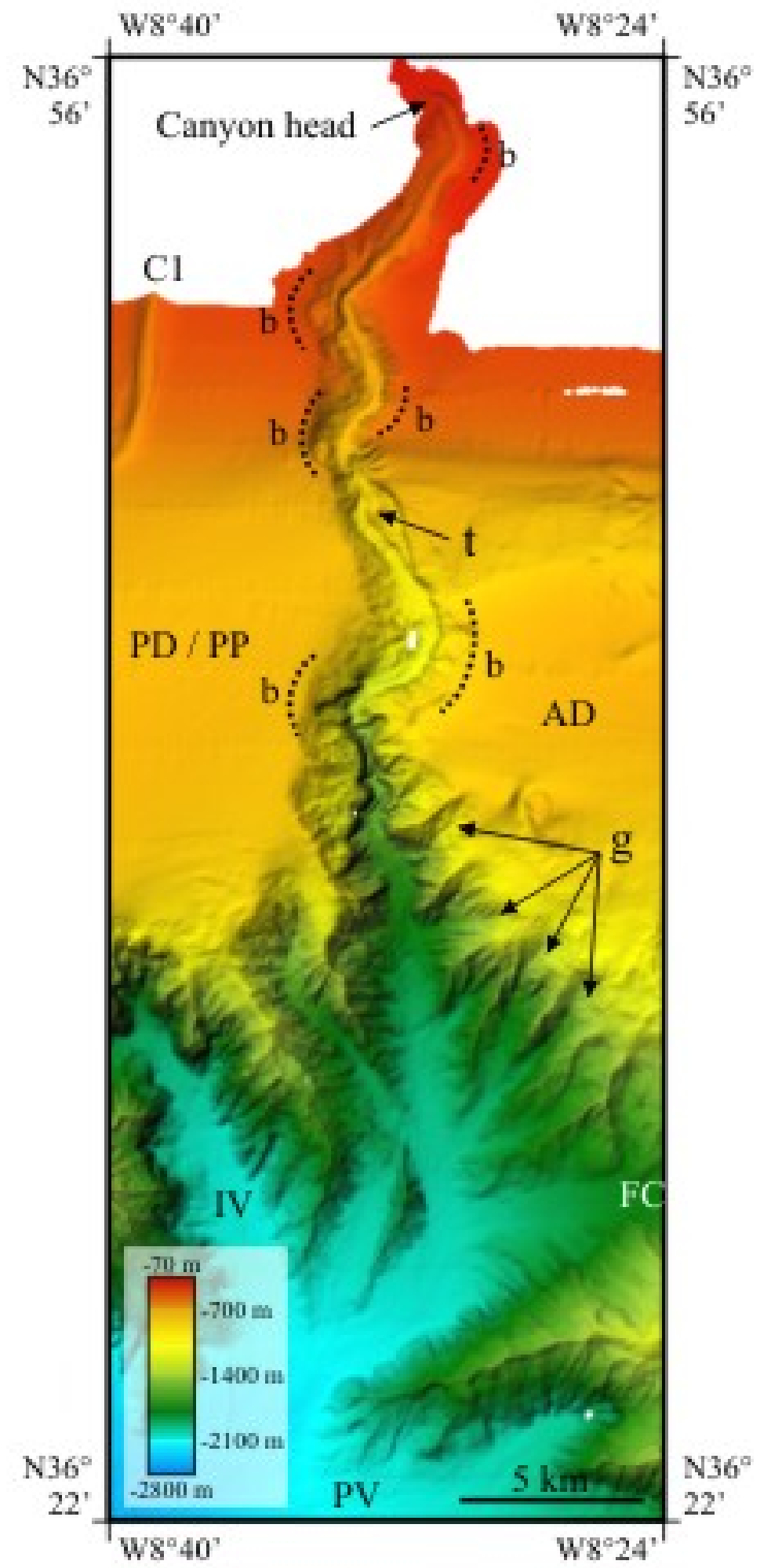

Fig. 4 Detailed bathymetric map of the Portimao Canyon (see location in Fig. 2a). The black dotted lines represent the bends (b) of the Portimao Canyon; t: terrace. For other abbreviations, see Fig. 2 


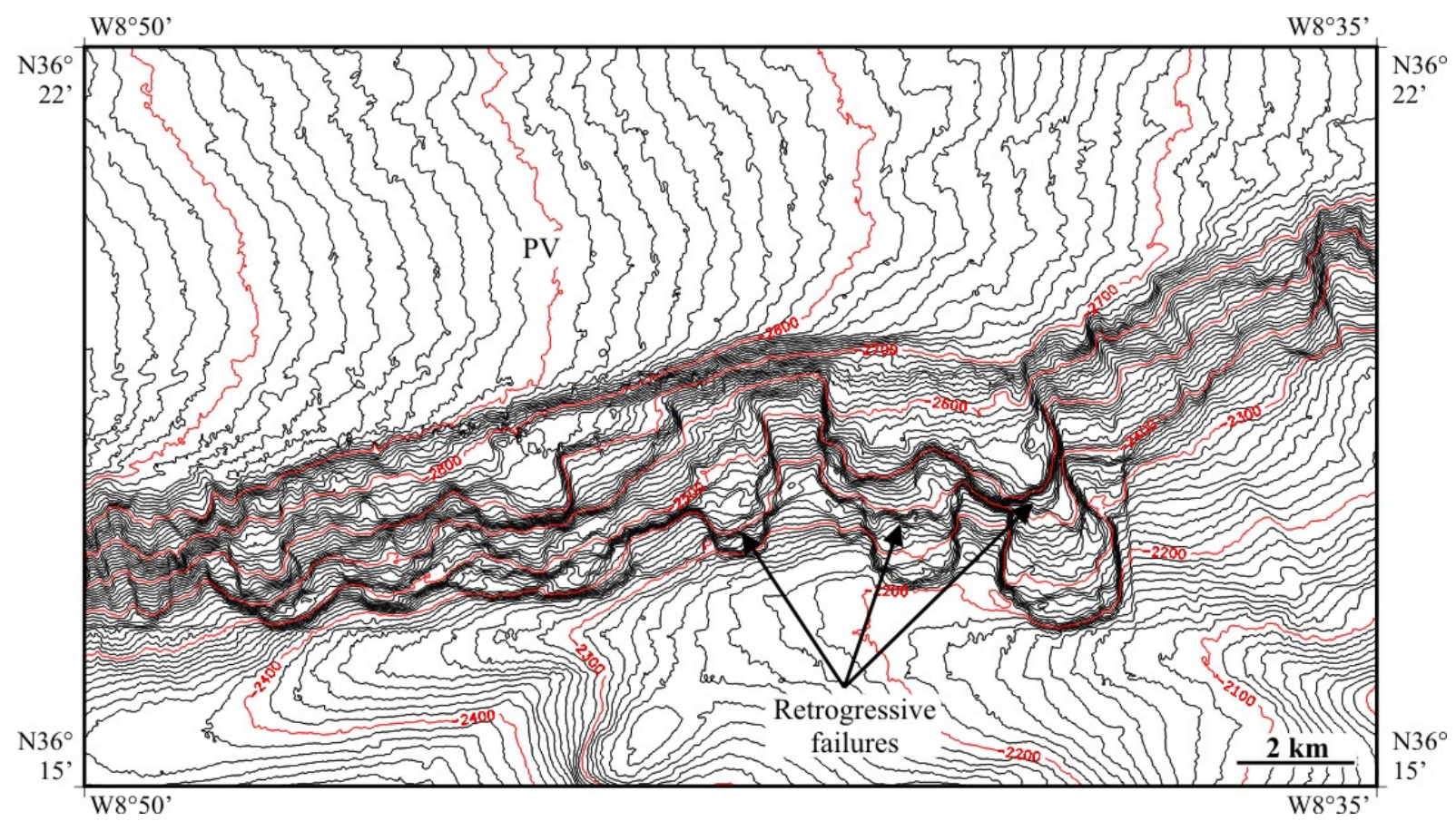

Fig. 5 Detailed bathymetric map of retrogressive failure scars (see location in Fig. 2a)

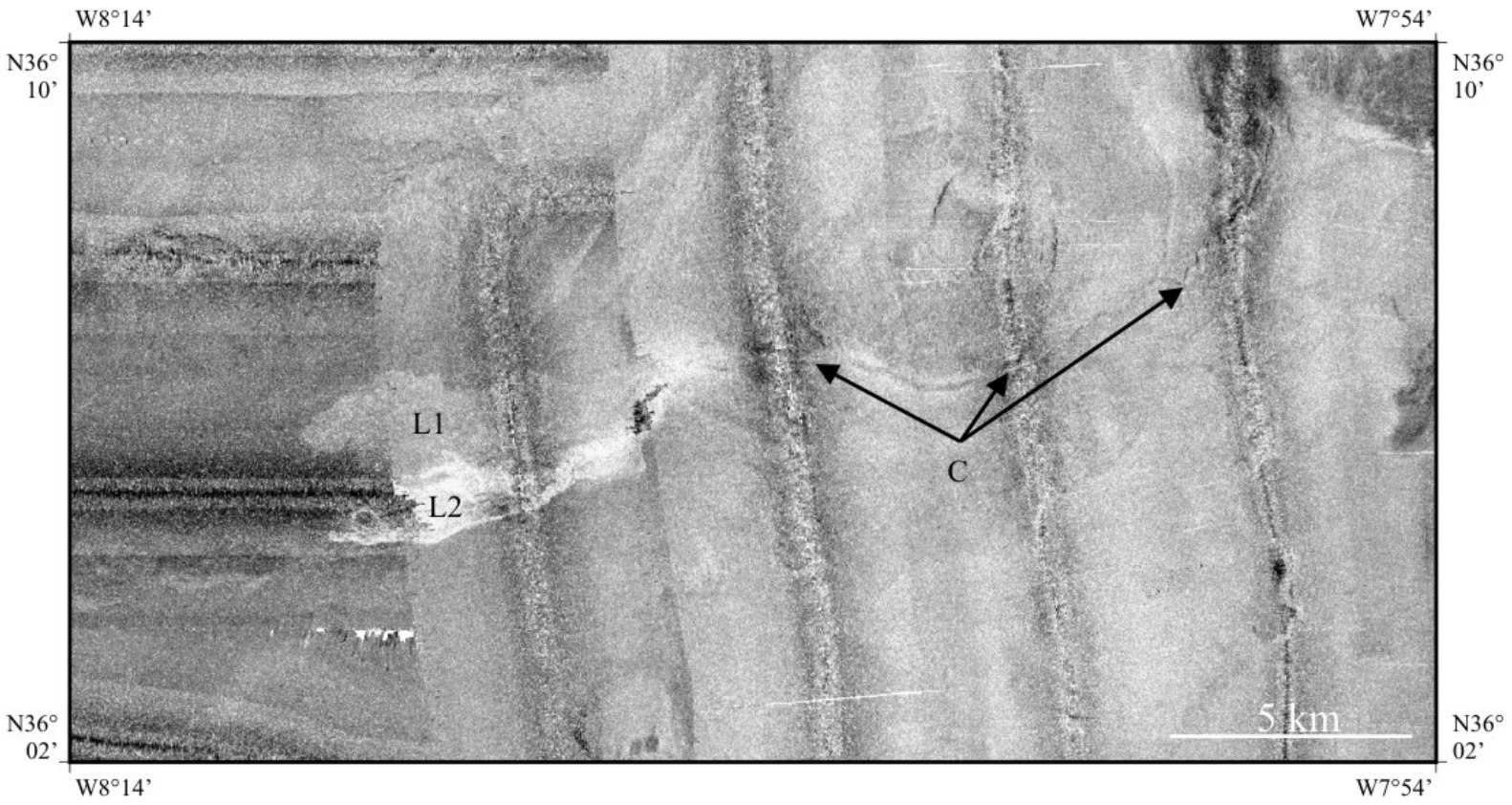

Fig. 6 Detailed acoustic image of the sandy lobe in the eastern part of the Cadiz Valley (see location in Fig. 2b). L1: most ancient lobe; L2: most recent lobe; C: feeder channel 


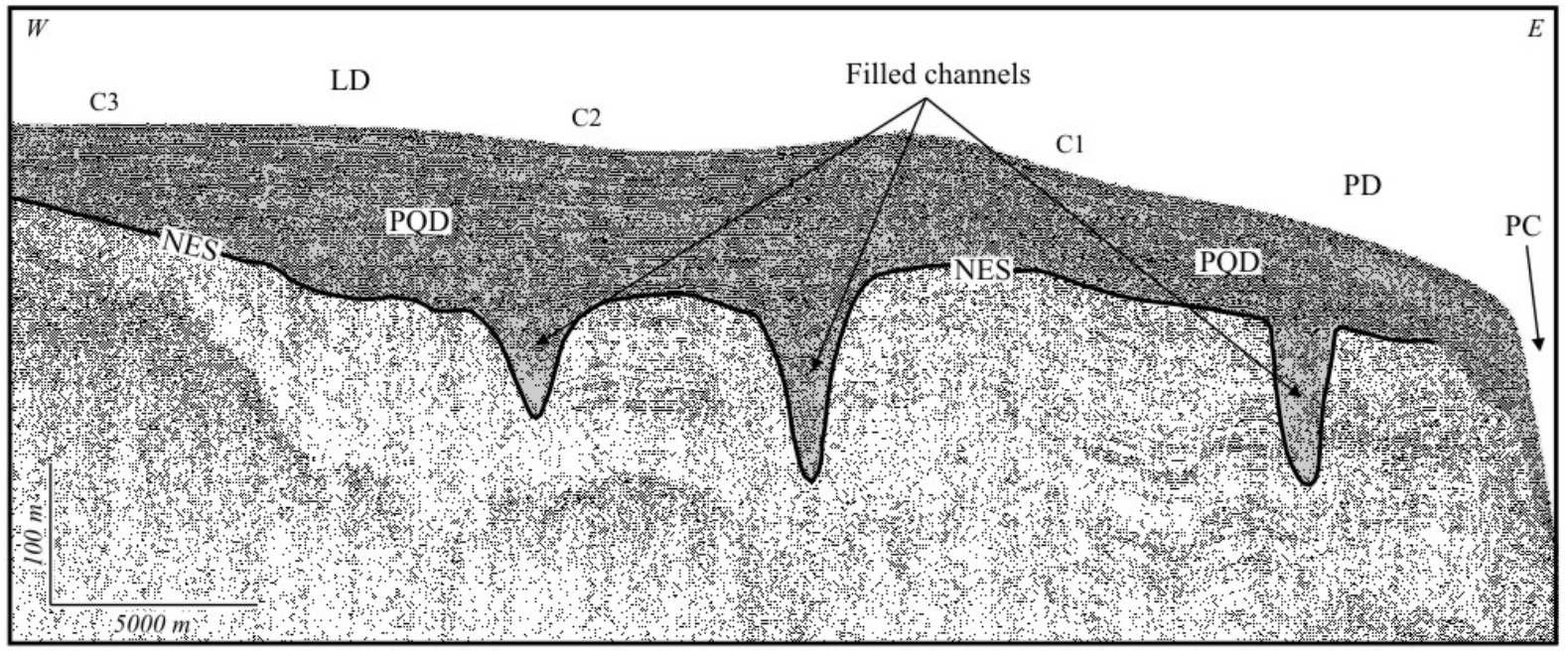

Fig. 7 E-W sparker seismic line (see location in Fig. 2a) across the Lagos and Portimao drifts, showing the paleo-system of filled channels. C1, C2, C3 indicate the longitudinal position of the three channels that are visible upslope on the bathymetric map in Fig. 2a. PQD: Plio-Quaternary deposits; NES: Neogene erosional surface. For other abbreviations, see Figs. 1 and $2 a$ 